\title{
PEMANFAATAN TEKNOLOGI INFORMASI DALAM PEMBELAJARAN PAI DI SD NEGERI CANDIREJO
}

\author{
Bekti Taufiq Ari Nugroho dan Mustaidah \\ IAIN Salatiga \\ bektitaufiq65@gmail.com dan musta'idahkintelan@gmail.com
}

\begin{abstract}
Abstrac
Utilization of Information Technology for Learning Islamic Education (PAI) in SD Negeri Candirejo can be grouped into three functions, namely: a) Independent / classical learning media; 2) Information Technology that is used for learning aids; 3) Information Technology related as a source of learning (learning resurces). Development of learning programs at SD Negeri Candirejo, namely: a) Behavioral technology program stage; b) Stage instructional technology; c) Stage performance technology. SD Negeri Candirejo, needs to use and maximize learning media that can support the development of Islamic religious education itself. PAI teachers at Candirejo Public Elementary School will play a role in managing the entire learning process by creating learning conditions in such a way that each child can learn effectively and efficiently. Starting from choosing materials, theories, methods, techniques, strategies and learning media. As an assessment of student learning outcomes (evaluator of student learning), teachers are required to play a role in continuously following the learning outcomes achieved by students from time to time. As a director of learning (teacher of learning), the teacher has a role to always generate, maintain, and increase the motivation of students to learn and as a guide in learning.
\end{abstract}

Keywoard: Utilization of Information Technology, Learning PAI

\begin{abstract}
Abstrak
Pemanfaatan Teknologi Informasi untuk Pembelajaran Pendidikan Agama Islam (PAI) di SD Negeri Candirejo dapat dikelompokkan ke dalam tiga fungsi, yaitu: a) Media Pembelajaran mandiri/klasikal; 2) Teknologi Informasi yang dimanfaatkan untuk alat bantu pembelajaran; 3) Teknologi Informasi yang terkait sebagai sumber belajar (learning resurces). Pengembangan program belajar di SD Negeri Candirejo yaitu: a) Tahap program behavioral technology; b) Tahap instructional technology; c) Tahap performance technology.
\end{abstract}

PROGRESS - Volume 7, No. 1, Juni 2019 
SD Negeri Candirejo, perlu menggunakan dan memaksimalkan media pembelajaran yang dapat menunjang terhadap pengembangan pendidikan agama Islam itu sendiri. Guru PAI di SD Negeri Candirejo akan berperan mengelola seluruh proses pemeblajaran dengan menciptakan kondisi-kondisi belajar sedemikian rupa sehingga setuiap anak dapat belajar secara efektif dan efisien. Mulai dari memilih materi, teori, metode, teknik, strategi maupun media pembelajaran. Sebagai penilai hasil belajar siswa (evaluator of student learning), guru dituntut untuk berperan secara terus-menerus mengikuti hasil-hasil belajar yang dicapai oleh siswa dari waktu ke waktu. Sebagai pengarah belajar (director of learning), guru berperan untuk senantiasa menimbulkan, memelihara, dan meningkatna motivasi siswa untuk belajar dan sebagai pembimbing dalam belajar.

Kata Kunci: Pemanfaatan Teknologi Informasi, Pembelajaran PAI

\section{A. Pendahuluan}

"Tiada hari tanpa teknologi", itulah kata-kata yang relevan dengan kehidupan saat ini. Karena manusia seakan tidak bisa hidup tanpa menggunakan teknologi, baik kalangan remaja, dewasa, orang tua bahkan anak-anakpun ikut menikmati dan membaur dengannya. Hal itu disebabkan tidak lain oleh efek yang diberikan olehnya, yang menjadikan urusan semakin ringan, cepat dalam penyelesaian masalah dan dapat menghasikan nilai tambah.

Di samping itu, "education is life and life is education" yang menegaskan bahwa manusia tidak akan pernah lepas dari proses pendidikan. Dalam kesehariannya selalu diliputi oleh nuansa-nuansa pendidikan, baik pendidikan dalam keluarga, masyarakat maupun pendidikan formal (sekolah /madrasah). Karena dengannyalah mereka akan dibentuk sesuai dengan pola yang dikehendaki meskipun terkadang output yang dihasilkan tidak sesuai dengan yang diinginkan.

Kedua istilah tersebut, yakni teknologi dan pendidikan, pada saat ini bagaikan dua sisi mata uang yang tidak bisa dipisahkan. Keduanya 
saling melengkapi dan memberikan pengaruh yang cukup besar. Tanpa pendidikan, teknologi tidak akan berkembang dan sebaliknya pendidikan tanpa teknologi akan berjalan secara lamban. Oleh karenanya dirasa cukup penting untuk membahasnya mengingat kebutuhan akan teknologi dalam aspek pendidikan merupakan tuntutan yang harus dipenuhi oleh setiap yang ingin mengembangkan dan meningkatkan wawasan keilmuan dan keterampilannya.

Dalam mengembangkan pendidikan agama Islampun peran teknologi sangat penting. Misalnya dalam kegiatan pembelajaran, media pembelajaran sangat perlu digunakan oleh pendidik agar peserta didik lebih bisa memahami dan merasa tertarik dengan materi yang disampaikan. Penjelasan tentang alam dan isinya atau proses penciptaan manusia itu akan lebih baik apabila menggunakan media terutama audio-visual. Dengan demikian peserta didik yang memiliki kemampuan beragam akan lebih mudah diatasi oleh pendidik.

Berdasarkan latar belakang masalah diatas, maka penulis merumuskan beberapa masalah dalam pembahasan ini sebagai berikut: 1) Apa manfaat teknologi dalam pembelajaran PAI di SD Negeri Candirejo? 2) Bagaimana peran teknologi dalam dunia pendidikan di SD Negeri Candirejo? 3) Bagaimana pengembangan pendidikan Islam melalui teknologi di SD Negeri Candirejo? 4) Bagaimana pola-pola pembelajaran dan peran guru PAI di SD Negeri Candirejo?

\section{B. Pengertian Teknologi PAI}

Istilah Teknologi kerap kali diungkapkan oleh hampir setiap orang karena sudah melebur dengan kehidupan seseorang. Sehingga, dirasa penting untuk menjelaskan definisi dari padanya. Secara etimologis, teknologi berasal dari dua kata yaitu, Teknikhos dan logos. 
Teknikhos berarti metode, yaitu suatu teknik untuk mencapai tujuan praktis, sedangkan Logos mempunyai makna ilmu. Teknik sebagai akar teknologi juga berarti cara untuk menghadapi, mengerjakan, menangani dan menyesuaikan hal atau masalah. Dalam pengertian yang lain, teknologi juga berarti metode teknis, khususnya dalam riset ilmiah dan juga metode pencapaian yang diinginkan. ${ }^{1}$ Di samping itu teknologi juga di artikan sebagai kemampuan teknik yang berlandaskan pengetahuan ilmu eksakta yang berdasarkan proses teknis; ilmu teknik. ${ }^{2}$

Secara terminologis Yusuf Hadimiarsa dalam bukunya mengatakan, bahwa teknologi merupakan keseluruhan sistem untuk mengelola hasil hingga melahirkan nilai tambah. ${ }^{3}$ Kemudian Nasution juga mengungkapkan bahwa teknologi adalah penerapan ilmu-ilmu dasar yang memecahkan masalah guna mencapai suatu tujuan tertentu. ${ }^{4}$ Namun di sisi lain dia mengatakan, bahwa teknologi adalah wujud dari upaya amnesia yang sistematis dalam menerapkan atau memanfaatkan ilmu pengetahuan/sains sehingga dapat memberikan kemudahan dan kesejahteraan bagi semua umat manusia di muka bumi ini.

${ }^{1}$ Komaruddin, Ensiklopedi Manajemen, Jakarta: Bumi Aksara, 1994, hlm. 848. Dalam sumber lain disebutkan bahwa teknologi memiliki definisi banyak. Pertama, kata ini mengacu pada sebuah objek fisik atau artefak, seperti mobil. Kedua, ia bisa mengacu pada sebuah kegiatan atau proses, system produksi mobil, pola-pola organisasi di sekitar teknologi kendaraan, perilaku dan pengharapan dari para pengguna mobil, dan lain sebagainya. Ketiga, teknologi bisa merujuk pengetahuan dan keterampilan yang diperlukan dalam produksi atau penggunaan teknologi. Tapi secara konvensional, teknologi telah menjadi pusat perhatian ilmu social dan melihat dampaknya terhadap masyarakat, atau secara lebih spesifik, atas dampaknya pada tenaga kerja dan organisasi. Ini sejalan dengan determinisme teknologi yang dihubungkan dengan beberapa bentuk Marxisme: teknologi memiliki kapasitas untuk menentukan jalannya evolusi sejarah. Lihat pada Adam Kuper dan Jessica Kuper, Ensiklopedi Ilmu-Ilmu Sosial, (Jakarta: PT RajaGrafindo Persada, 2008), hlm. 1087.

${ }^{2}$ Dessy Anwar, Kamus Lengkap Bahasa Indonesia, Surabaya: Karya Abditama, 2001,hlm. 498. hlm. 4.

${ }^{3}$ Yusuf Hadimiarsa, Teknologi Komunikasi Pendidikan, Jakarta: Rajawali, 1986,

${ }^{4}$ Nasution, Teknologi Pendidikan, Jakarta: Bumi Aksara, 2008, hlm. 2.

PROGRESS - Volume 7, No. 1, Juni 2019 
Sementara AECT (Association of Education and Communication Technology) 2004, memberikan definisi sebagai berikut, "Educational technology is the study and ethical practice of facilitating learning and improving performance by creating, using, and managing appropriate technological processes and resources", yakni teknologi pendidikan adalah studi dan praktek etis dalam upaya memfasilitasi pembelajaran dan meningkatkan kinerja dengan cara menciptakan, menggunakan atau memanfaatkan, dan mengelola proses dan sumber-sumber teknologi yang tepat. Jelas, tujuan utamanya masih tetap untuk memfasilitasi pembelajaran (agar efektif, efisien dan menarik) dan meningkatkan kinerja.

Sedangkan Teknologi Instruksional adalah teori dan praktek dalam mendesain, mengembangkan, memanfaatkan, mengelola, dan menilai proses-proses maupun sumber-sumber belajar. Definisi ini lebih operasional dari pada rumusan tahun 1977 yang terlalu rumit. Definisi ini menegaskan adanya lima domain (kawasan) teknologi pembelajaran, yaitu kawasan desain, kawasan pengembangan, kawasan pemanfaatan, kawasan pengelolaan, dan kawasan penilaian baik untuk proses maupun sumber belajar. Seorang teknolog pembelajaran bisa saja memfokuskan bidang garapannya dalam salah satu kawasan tersebut.

Di samping itu, Tom Cutchall (1999) mengemukakan bahwa "Instructional technology is the research in and application of behavioral science and learning theories and the use of a systems approach to analyze, design, develop, implement, evaluate and manage 
the use of technology to assist in the solving of learning or performance problems. $^{5}$

Semua teknologi pada hakikatnya adalah proses untuk mendapatkan nilai tambah. Proses itu memang menghasilkan produk yang bermanfaat. Sedangkan pemanfaatan produk itu tidak terlepas dari unsur budaya lain atau sistem yang telah ada. Jacques Ellul (1967), seorang sosiologi Prancis, mengartikan teknologi sebagai keseluruhan metode yang secara rasional mengarah dan memiliki ciri efisiensi dalam setiap kegiatan manusia. $^{6}$ Gary J. Anglin (1991) mendefinisikan teknologi sebagai penerapan ilmu-ilmu perilaku dan alam serta pengetahuan lain secara bersistem dan mensistemi untuk memecahkan berbagai masalah yang dihadapi manusia. ${ }^{7}$

Dari definisi tersebut dapat diambil kesimpulan bahwa teknologi merupakan metode teknis yang digunakan dalam rangka mencapai tujuan tertentu dan hasil yang maksimal (nilai tambah). Metode ini tidak hanya dipakai dalam satu sektor kehidupan, melainkan dapat dimanfaatkan pada banyak sektor. Dalam pembahasan ini, pendidikan mendapatkan perhatian utama untuk menjadi bahan kajian yang berhubungan dengan teknologi.

${ }^{5}$ http://www.arches.uga.edu/cutshall/tomitdef.html, pada hari Sabtu, 16 Juni 2012. Definisi menurut Cutchall ini sama seperti definisi AECT 1994. Dia menekankan bahwa teknologi pembelajaran merupakan penelitian dan aplikasi ilmu perilaku dan teori belajar dengan menggunakan pendekatan sistem untuk melakukan analisis, desain, pengembangan, implementasi, evaluasi dan pengelolaan penggunaan teknologi untuk membantu memecahkan masalah belajar dan kinerja. Tujuan utamanya adalah pemanfaatan teknologi (soft-technology maupun hard-technology) untuk membantu memecahkan masalah belajar dan kinerja manusia.

${ }^{6}$ Yusuf Hadi Miarso, Menyamai Benih Tekhnologi Pendidikan, Jakarta: Rajawali Press, 2007, hlm. 302. 302.

${ }^{7}$ Yusuf Hadi Miarso, Menyamai Benih Tekhnologi Pendidikan, ..., Ibid, 2007, hlm. PROGRESS - Volume 7, No. 1, Juni 2019 
Selanjutnya, berdasarkan paparan sebelumnya, maka teknologi pendidikan dapat diartikan sebagai kajian dan praktik untuk membantu proses belajar dan meningkatkan kinerja dengan membuat, menggunakan, dan mengelola proses dan sumber teknologi yang memadai. ${ }^{8}$ Istilah teknologi pendidikan sering dihubungkan dengan teori belajar dan pembelajaran. Bila teori belajar dan pembelajaran mencakup proses dan sistem dalam belajar dan pembelajaran, teknologi pendidikan mencakup sistem lain yang digunakan dalam proses mengembangkan kemampuan manusia.

\section{Sejarah Ringkas Perkembangan Teknologi PAI}

Teknologi berkembang sejak awal periode Islam. Apresiasi umat Islam terhadap ilmu pengetahuan pada saat itu sangat menakjubkan. Pada bidang astronomi, ilmuwan Islam mendirikan beberapa observatorium Bait al-Hikmah di Baghdad, observatorium Dar alHikmah di Kairo dan observatorium Taqi al-Din di Istambul. Orangorang barat baru mendirikan dan memiliki observatorium sendiri pada tahun 1580 di Tycho Brahe (Denmark). ${ }^{9}$ Pada saat itu pula, telah banyak lahir ilmuwan dan ahli pengembangan teknologi muslim, diantaranya: ${ }^{10}$

1. Jabir Ibnu Hayyan atau Jaber (721-815 H) adalah orang pertama yang menggunakan metode empiris dalam kegiatan observasinya, Jaber mendirikan bengkel dan menggunakan tungku untuk mengelola mineral dan mengekstrasi zat kimia dari mineral itu dan mengklasifikasikannya.

\footnotetext{
${ }^{8}$ Richey R.C, Reflections on the 2008 AECT Definitions of the Field, TechTrends: 2008, hlm. 24-25.

${ }^{9}$ Wisnu Arya Wardhana, Melacak Teori Einsten dalam Al-Quran, Yogyakarta: Pustaka Pelajar, 2005, hlm.13.

${ }^{10}$ Soejoeti, al-Islam dan IPTEK, Jakarta: Raja Grafindo, 1998, hlm. 105-115.
} PROGRESS - Volume 7, No. 1, Juni 2019 
2. Muhammad Ibnu Zakariyyah al-Razi, adalah ilmuwan yang menggunakan alat khusus proses yang lazim dilakukan ahli kimia, seperti distalasi, kristalisasi, kalsinasi dan sebagainya. Dalam konsepsi al-Razi golongan logam dibagi menjadi, jiwa tubuh, batu, vitricl, borax dan garam.

3. Abu Ali al-Hasan Ibnu Haithan (965-1039 H) atau al-Hazen, berhasil membuat cermin-cermin parabola dan sferis (bulat) serta menemukan perbandingan antara sudut datang dan sudut pergi pada bidangbidang datar sehingga karyanya merupakan hasil penelitian yang lebih dahulu dari karya-karya di barat berkaitan dengan sifat-sifat cermin dan lensa.

Salah satu pengaruh kebangkitan eropa adalah penerjemah ilmuilmu Islam dari bahasa arab ke bahasa latin. Bangsa barat kemudian mulai banyak mempelajari ilmu pengetahuan dan teknologi. Munculnya paradigma Newtonian yang bersifat mekanistik deterministik, yaitu apabila kondisi awal dari sesuatu dapat ditentukan terlebih dahulu secara benar dan akurat, maka kondisi selanjutnya dapat diprediksi secara lebih benar dan tepat. Paradigma inilah yang memacu timbulnya revolusi industri di Inggris dan menjalar ke daratan Eropa, bahkan ke Amerika. ${ }^{11}$

Terjadinya mekanisasi pada abad ke-17 diikuti energisasi pada abad ke-18, yaitu ditemukannya mesin uap, kapal uap, kereta uap, motor uap, dan penumbuk gandum. Optimalisasi pada abad ke-18 dan 19 dan otomatisasi pada abad ke-19 dan 20, dengan mesin-mesin mobil, pesawat terbang dan sebagainya. ${ }^{12}$ Sedangkan menurut Micnio Kaku ada

11 Umar A. Janie, Paradigma dan Regulitas Perkembangan IPTEK; dalam Religiusitas IPTEK, ed, Abdul Munir Mulkam, et.al, Yogyakarta: Pustaka Pelajar, 1998, hlm. 4.

${ }^{12}$ Abdul Minir Mulkam, Paradigma dan Regulitas Perkembangan IPTEK; dalam Religiusitas IPTEK, ed, Ibid., 1998, hlm. 5.

PROGRESS - Volume 7, No. 1, Juni 2019 
tiga revolusi ilmu pengetahuan dan teknologi pada abad ke 20 dan 21, antara lain, ${ }^{13}$ adalah:

1. Revolusi Quantum: Revolusi Quantum dengan segala aplikasi teknologi dan rekayasa industrinya telah memungkinkan manusia membuat bahan-bahan atau materi-materi baru non alamiah dengan kekuatan dan sifat-sifat yang lebih baik dibanding materi alamiah.

2. Revolusi Komputer: Revolusi komputer dengan segala aplikasinya juga telah memungkinkan umat manusia mengerti bagaimana sesungguhnya otak manusia bekerja. Komputer dengan sistem kerja robotik yang meniru kerja otak manusia sedang dirancang untuk dibuat.

3. Revolusi Biomolekuler: Revolusi ini memberikan hal-hal baru dalam dunia kedokteran, seperti rekayasa genetika, trans genetik dan cloning, telah memungkinkan manusia untuk mengerti lebih dalam dari mekanisme kehidupan.

\section{Metode Penelitian}

Pendekatan yang digunakan dalam penelitian ini adalah pendekatan kualitatif dengan jenis penelitian lapangan (field research) yang bersifat deskriptif kualitatif, karena peneliti berusaha mendeskripsikan suatu gejala, peristiwa dan kejadian sebagaimana tujuan dari penelitian ini, yaitu untuk mengetahui pemanfaatan teknologi informasi dalam pembelajaran PAI. Pendekatan ini digunakan karena data yang dikumpulkan berupa kata-kata, dan bukan angka. Sedangkan menurut Bogdan dan Taylor prosedur penelitian yang melibatkan data deskriptif berupa kata-kata tertulis atau lisan dari orang atau pelaku yang

${ }^{13}$ Abdul Minir Mulkam, Paradigma dan Regulitas Perkembangan IPTEK; dalam Religiusitas IPTEK, ed, Ibid., 1998, hlm. 112-113.

PROGRESS - Volume 7, No. 1, Juni 2019 
dapat diamati ${ }^{14}$. Penelitian berjenis kualitatif, ${ }^{15}$ biasanya memuat tentang jenis pendekatan penelitian, data dan sumber data, teknik pengumpulan data, dan teknik analisis data.

Penelitian kualitatif, disebut juga "penelitian subjektif" dan "penelitian reflektif", karena peneliti melakukan pengujian sendiri secara kritis selama proses penelitian. Langkah-langkah yang dipakai oleh peneliti dalam penelitian di SD Negeri Candirejo adalah adanya masalah yang terjadi, selanjutnya peneliti membuat informasi yang dibutuhkan, menentukan prosedur pengumpulan data, pengolahan data atau informasi, dan yang terakhir menarik kesimpulan penelitian.

Penelitian kualitatif harus mengetahui prosedur pengumpulan data. Menurut salah satu pakar, Cresswell, menyebutkan bahwa "The data collection step involve (a) setting the boundaries for the study, (b) collecting the information through observations, interviews, documents, and visual materials, and (c) establishing the protocol for recording information ". 16 Maksud dari pemaparan Cresswell ini dapat diartikan bahwa langkah-langkah pengumpulan data meliputi: (a) setting yang berhubungan dengan study, (b) pengumpulan informasi melalui observasi, wawancara, dokumentasi dan materi-materi visual, (c) menetapkan protokol perekam informasi.

Teknik keabsahan data yang digunakan dalam penelitian ini adalah triangulasi. Triangulasi adalah teknik pemeriksaan keabsahan data yang memanfaatkan sesuatu lain di luar data itu untuk keperluan

14 Moleong, lexy J. Metodologi Penelitian Kualitatif. Bandung: Remaja Rosdakarya, 2011, hlm. 3

15 Maslikhah, Melejitkan Kemahiran Menulis Karya Ilmiah Bagi Mahasiswa, Yogyakarta: Trusth Media Publishing, 2013, hlm. 67.

${ }^{16}$ Creswell, John W, Reseach design Qualitative \& Quantitative Approaches. United States of America: Sage Publication, 1994, hlm. 148.

PROGRESS - Volume 7, No. 1, Juni 2019 
pengecekan atau sebagai pembanding terhadap data itu. ${ }^{17}$ Senada dengan Denzin, ${ }^{18}$ mengemukakan bahwa:

1. Data triangulation: the use of variety of data source in a study.

2. Investigator triangulation: the use of several different reseaches or evaluator.

3. Theory triangulation: the use of multiple methods to study a single sent of data.

4. Methodological triangulation: the use of multiple methods to study a single problem.

Jika diterjemahkan bebas tipe dasar triangulasi diatas menggunakan empat prinsip yaitu: Teknik Analisis Data

1. Triangulasi data: adalah penggunaan beragam sumber data dalam satu kajian.

2. Triangulasi investigator (sumber): penggunaan beberapa evaluator yang berbeda.

3. Triangulasi teori : penggunaan sudut pandang ganda dalam menafsirkan.

4. Triangulasi metodologis yaitu penggunaan metode ganda untuk mengkaji satu masalah.

Analisis data kualitatif dilakukan bersamaan dengan proses pengumpulan data. Teknik analisis yang dilakukan dengan menggunakan teknik analisis data yang dikemukakan oleh Miles dan Huberman, ${ }^{19}$ mencakup tiga kegiatan yang bersamaan: reduksi data, penyajian data dan penarikan kesimpulan (verifikasi).

${ }^{17}$ Lexy J. Moleong, Metodologi Penelitian Kualitatif, ..., 2007, hlm. 330.

18 Norman K.Denzin, Handbook of Qualitative Research, California : Sage Publication, 2000, p. 391.

${ }_{19}$ Miles, M.B \& Huberman, A.M, Analisa Data Kualitatif: Penerjemah. TjetjepRohendi R. Universitas Indonesia Press, 1992, hlm. 19-20.

PROGRESS - Volume 7, No. 1, Juni 2019 


\section{E. Manfaat Teknologi dalam Pembelajaran PAI di SD Negeri Candirejo}

Penemuan macam-macam alat dan mesin mempengaruhi dan mengubah cara hidup, norma-norma, cara berfikir dan cara kerja manusia. Alat-alat teknologi juga mempengaruhi pembelajaran, antara lain metode penyampian dan cara penilaian. Alat-alat pembelajaran kebanyakan tidak diciptakan khusus untuk keperluan pembelajaran, kecuali mesin belajar. Selain itu pembelajaran memanfaatkan hasil teknologi seperti film, radio, TV, komputer dan sebagainya. ${ }^{20}$

Adanya alat pembelajaran yang serba lengkap belum tentu menjamin pemanfaatannya dalam pendidikan, sering terjadi gap antara "hardware" dan "software". Banyaknya ragam alat pendidikan juga menimbulkan kesulitan untuk memiliki alat yang sesuai dengan bahan ajar atau materi pelajaran tertentu. Untuk memanfaatkan alat teknologi pendidikan dibutuhkan keterampilan dari pihak guru, serta sikap positif terhadap perkembangan alat teknologi pendidikan. Betapapun majunya alat teknologi pendidikan senantiasa memerlukan peran guru.

Selain itu tujuan pembelajaran, jika lebih spesifik maka akan lebih bagus. Karena tujuan pembelajaran yang spesifik, memudahkan pendidik dalam membimbing siswa untuk mencapai target setelah pembelajaran telah diselesaikan. ${ }^{21}$ Oleh karena itu perlu adanya keahlian dalam pengembangan tujuan pembelajaran dari tujuan instruksional umum kepada tujuan instruksional khusus. Selain dari itu sebaiknya tujuan pembelajaran PAI juga disampaikan kepada siswa sebelum proses

\footnotetext{
${ }^{20}$ Nasution, Teknologi Pendidikan, Jakarta: Bumi Aksara, 1994, hlm. 113.

${ }_{21}$ Mudhoffir, Teknologi Instruksional, Bandung: Remaja Rosdakarya, 1996, hlm.64.
} 
pembelajaran dimulai. Hal ini bertujuan agar siswa dapat mengaitkan prilaku atau prestasi yang diharapkan. ${ }^{22}$

Komunikasi elektronik telah menjadi salah satu strategi terbaru untuk mendukung proses pembelajaran. ${ }^{23}$ Aspek paling penting dalam proes pembelajaran adalah kemampuan peserta didik dan pengajar untuk melakukan komunikasi tanpa batas waktu. Proses pemeblajaran secara konvensional menggunakan aktivitas yang ada di kelas begitu kegiatannya selesai, maka interaksi juga usai. Oleh karena itu, komunikasi di kelas konvensional bersifat statis.

Bachari (2001) menyatakan, bahwa pemanfaatan teknologi informasi dalam konteks pemeblajarn pada dasarnya dapat berupa:

1. Media proses belajar mengajar jarak jauh.

2. Media pembelajaran mandiri.

3. Alat uji kemahiran.

4. Media promosi lemabga penyelengara pendidikan.

5. Media penyedia bahan ajar.

6. Sarana komunikasi profesional bagi par apengjaar (guru).

Selanjutnya Bachari, ${ }^{24}$ mengemukakan bahwa pembuagan jaringan komunikasi tidaklah terlalu sulit sebab saat ini sangat banyak sofwere yang memberikan kemudahan bagi kita untuk mendesai sebauh web.

Mendesain web semacam ini tidaklah berbeda dengan rancangan yang diperugnkan oleh situs-situs surat kabar, hibutan, bisnis, dan perbankn. Sofwere-sofwere yang sering dipergunakan untuk mendesai sebuah web

\footnotetext{
${ }^{22}$ Mudhoffir, Teknologi Instruksional, ..., Ibid., 1996, hlm. 29.

${ }^{23}$ Ivor K. Davis. Teknologi Pendidikan "Contoh Yang Sempurna Paradigma dan Model'. London,1997, hlm. 167-180.

${ }^{24}$ Bachari, A. Dutha. 2001. "Kejahatan (Intelektual) dalam dunia Cyber". Artikel pada Harian Umum Galamedia, hlm. 4.
} 
secara umum adalah MS Publisher, MS Front Page, dan Net Scope Composer, setiap sofwere tersebut memiliki fasilitas yang berbeda.

1. MS Publiser, menyediakan falitas yang sangat praktis dalam menggunakan sofwere ini, kita cukup mengisi materi aywng akan ditampilkan dalam web, karena sofwere ini telah menyediakan format web beserta html nya.

2. MS Front Page, tugas kita hanya membuat gambar dan mengetik naskah untuk membangun sebuah web. Dapat pula kita sertakan video live dalam situs yang kita bangun dengan menggunakan sofwere ini. Karakteristik sofwere itu harus kita pahami dan pemanfaatanya harus kita sesuaikan dengan kebutuhan web yang akan kita rancang.

Hal yang penting dan prinsip dalam proses pembelajaran baik dalam konteks langsung tatap muka atau melalui sarana komunikasi melalui jaringan internet adalah komunikasi konvergen, ${ }^{25}$ yang memiliki ciri utama bahwa komunikasi itu pada adsarnya menjalin hubungan (komunikasi) saling pengertian yang dibangun melalui tahapan pemahaman, interprestasi, pengertian dan kegiatan diantara peserta didik untuk kemudian dicapai saling kesepahaman.

Adapun pemanfaatan Teknologi Informasi untuk Pembelajaran Pendidikan Agama Islam (PAI) di SD Negeri Candirejo dapat dikelompokkan ke dalam tiga fungsi, yaitu:

1. Media Pembelajaran mandiri/klasikal.

Media pembelajaran mandiri/ klasikal ini antara lain pemutaran film dan $\mathrm{CD}$ interaktif, pertama, pemutaran film, guru

${ }^{25}$ Rogers, Everett M. Communication Technology, The New Media in Society. New York. The Free Press, 1986, p. 44. Lihat juga bukunya Abdulhak, Rancang Bangun Konsep Teknologi Pendidikan, Bandung: Remaja Rosda Karya, 2001, hlm.12.

PROGRESS - Volume 7, No. 1, Juni 2019 
dapat memilah jenis film yang ada yaitu film yang bersifat given artinya suatu paket judul film yang telah tersedia dan relevan dengan pembelajaran pendidikan Agama Islam. Kedua, penggunaan CD interaktif lebih"Maju" dari pemutaran film, karena siswa dapat melakuakn"interaksi" atau perlakuan terahdap program yang ditawarkan pada $\mathrm{CD}$, misalnya $\mathrm{CD}$ interaktif soal-jawab Pendidikan Agama Islam dikemas dalam bentuk permainan seperti dalam "Who want to Be Millionare". Madrasah/sekolah dalam hal ini guru Pendidikan Agama Islam harus memiliki koleksi film atau CD interaktif yang terkait dengan materi Pendidikan Agama Islam interaktif yang terkait dengan materi Pendidikan Agama Islam sesuai kurikulum yang berlaku.

2. Teknologi Informasi yang dimanfaatkan untuk alat bantu pembelajaran.

Teknologi Informasi yang dimanfaatkan untuk alat bantu pembelajaran yaitu, pemanfaatan softwere (komputer) untuk pemeblajaran Pendidikan Agama Islam. Beberapa contoh software pendidikan yang dikelan diantaranya; Computer Assisted Instruction (CAI) yang umumnya software ini sangat baik untuk keperluan remidial. Intelligent computer assited learning (ICAL), dapat digunakan untuk material atau konsep. Computer Assisted Training (CAT), Computer Assisted Design (CAD), Computer Assisted Media (CAM) dan sebagainya.

3. Teknologi Informasi yang terkait sebagai sumber belajar (learning resurces).

Teknologi Informasi yang terkait sebagai sumber belajar (learning resurces) dalam bentuk internet dengan segala 
komponennya. Materi yang ditampilkan dalam sebauh eb yang terkait denagn pendidian Agama Islam dapat dilacak terlebih dahulu oleh guru dan dipraktekkan langsung oleh murid. Maksud pelacakan oleh guru agar materi atau informasinya relevan dengan tujuan kurikuler PAI.

\section{F. Peran Teknologi dalam Dunia Pendidikan di SD Negeri Candirejo}

Penggunaan teknologi sangatlah bermanfaat dalam dunia pendidikan, termasuk pendidikan Islam. Karena pendidikan Islam merupakan sub sistem Pendidikan Nasional Indonesia. Perjalanan Pendidikan Islam tidak terlepas dari pasang surutnya sistem Pendidikan Nasional itu sendiri, sebagaimana tidak terlepasnya umat Islam ketika kita membicarakan nasib bangsa ini, dan bahkan Pendidikan Islam mempunyai sejarah panjang di Indonesia yang telah ikut mewarnai kehidupan bangsa ini baik masa sebelum penjajahan bahkan setelah Indonesia merdeka.

Berdasarkan Negara Kesatuan Republik Indonesia, dimana masyarakatnya mayoritas memeluk Agama Islam, seharusnya Pendidikan Islam mendasari pendidikan-pendidikan lainnya, serta menjadi primadona bagi peserta didik, orang tua, maupun masyarakat. Demikian juga halnya dalam upaya peningkatan mutu pendidikan seharusnya Pendidikan Islam dijadikan tolok ukur dalam membentuk watak dan pribadi peserta didik, serta membangun moral bangsa. ${ }^{26}$

Upaya-upaya yang dilakukan pemerintah, maupun para pakar pendidikan untuk peningkatan mutu pendidikan tak terkecuali Pendidikan Islam sudah sejak lama namun hasil yang dicapai belumlah maksimal. Upaya-upaya peningkatan mutu pendidikan masih bersifat

\footnotetext{
${ }^{26}$ Abdul Majid, Pendidikan Agama Islam Berbasis Kompetensi, Bandung: PT Remaja Rosdakarya, 2004, hlm. 161.
} 
parsial, terkotak-kotak dan tidak komprehensif. Sehingga wajar apabila output peserta didik dari pendidikan Islam kurang memberikan hasil yang maksimal baik terhadap peserta didik, orang tua, maupun masyarakat.

Untuk mengatasi kelemahan-kelemahan ini maka teknologi pendidikan dalam pendidikan Islam juga diterapkan, agar dapat mendukung pendidikan Islam itu sendiri. Penggunanaan teknologi dalam praktek pendidikan Islam harus juga melihat situasi dan kondisi dimana teknologi pendidikan itu akan digunakan dalam praktek pendidikan Islam.

Jangan salah mengartikan bahwa teknologi pendidikan tidak hanya berhubungan dengan peralatan teknik dan media yang dipakai dalam pendidikan, seperti: overhead, projector, televise, slide projector, audio tape, rekaman video dan sebagainya. ${ }^{27}$

Teknologi pendidikan memiliki arti yang lebih luas dari penjelasan di atas, teknologi pendidikan dapat didefinisikan pengembangan, penerapan dan evaluasi sistem, teknik dan alat untuk tujuan meningkatkan proses belajar mengajar bagi manusia. ${ }^{28}$ Jadi dalam prakteknya teknologi pendidikan dalam pendidikan bukan hanya penggunaan alat-alat elektronik dalam pembelajaran di kelas tetapi di luar itu teknologi pendidikan juga memiliki peran.

Misalnya dalam prakteknya teknologi pendidikan dalam pendidikan Islam, perumusan tujuan pendidikan didasarkan pada nilainilai keIslaman dengan memberi pengaruh kepada penampilan, sikap, 1988, hlm. 1 .

${ }^{27}$ Fred Percival dan Henry Ellington, Teknologi Pendidikan, Jakarta: Erlangga,

${ }^{28}$ Fred Percival dan Henry Ellington, Teknologi Pendidikan, ...., Ibid, 1998, hlm. 9. 
tingkah laku dan amalnya sehingga menghasilkan akhlaq yang baik. Akhlaq ini perlu dan harus dilatih melalui latihan membaca dan mengkaji al-Qur'an, salat malam, saum (puasa) sunnah. Selain itu latihan akan menghantarkan dirinya memiliki kebiasaan yang akhirnya menjadi gaya hidup sehari-hari. Proses penetapan tujuan untuk menghasilkan akhlak yang baik sampai proses untuk membentuk dan melatih akhlak tersebut merupakan proses dalam teknologi pendidikan.

Teknologi pendidikan memegang peran yang penting untuk masa sekarang dan masa yang akan datang. Teknologi pendidikan merupakan pendekatan sistematis dalam merencanakan, melaksanakan dan mengevaluasi proses pembelajaran. Dengan adanya teknologi pendidikan, maka terjadilah kecenderungan-kecenderungan, sebagai berikut: $^{29}$

1. Terjadinya arah gradual ke arah pendekatan belajar yang lebih berpusat terhadap peserta didik (student centered approach learning). Perubahan ini ditandai oleh semakin bertambahnya penggunaan media belajar yang diindividualisasikan.

2. Pertambahan secara eksplosif penggunaan teknologi informasi dan komunikasi secara praktis dalam semua aspek pendidikan.

Kurikulum dan teknologi pendidikan saling melengkapi. Teknologi pendidikan berfungsi memperkuat pengembangan kurikulum. Bagaimana kurikulum dikembangkan, maka itu menjadi fungsi teknologi pendidikan. Terminologi teknologi tidak hanya berkaitan tentang alat-alat atau mesin, namun juga berkaitan dengan kegiatan menerapkan ilmu atau pengetahuan atau usaha memecahkan masalah.

${ }^{29}$ Munir, Kurikulum Berbasis Tekhnologi Informasi dan Komunikasi, Bandung: Alfabeta, 2008, hlm. 39.

PROGRESS - Volume 7, No. 1, Juni 2019 
Dengan demikian teknologi adalah penerapan ilmu pengetahuan yang sistematis untuk melakukan suatu kegiatan.

Teknologi pendidikan memiliki peran yang besar pada pengembangan kurikulum karena dalam merancang, menyusun, dan mengembangkan kurikulum menjadi sumber yang menentukan strategi pembelajaran dengan menempatkan pengajar tidak hanya sebagai pelaksana, namun juga sebagai perekayasa dalam proses pembelajaran. Rekayasa dilakukan pengajar yaitu pada prangkat keras dan pada perangkat lunak atau program belajarnya.

Langkah-langkah pengembangan program belajar di SD Negeri Candirejo yaitu:

1. Tahap program behavioral technology, tahap ini adalah pengembangan program pembelajaran dengan menganalisis tingkah laku dalam proses pembelajaran dan setelah mengikuti kegiatan pembelajaran.

2. Tahap instructional technology, kemampuan-kemampuan hasil teknologi tingkah laku dikembangkan ke dalam pengembangan program pembelajaran yang terpilih.

3. Tahap performance technology, pengembangan program pembelajaran selalu menggunakan teknik analisis kebutuhan belajar untuk memperoleh informasi mengenai kemampuan yang diperlukan peserta didik. Bahkan setelah peserta didik menyelesaikan kegiatan belajar selalu dilakukan analisis umpan balik untuk melihat kesesuaian hasil belajar dengan kebutuhan belajar. 


\section{G. Pengembangan Pendidikan Islam melalui Teknologi di SD Negeri Candirejo}

Sebagaimana diuraikan sebelumnya bahwa pendidikan agama Islam merupakan sub sistem pendidikan nasional sehingga perlu juga perhatian dari elemen pendidikan. Karena dengannya akan mengalami perkembangan yang selaras dengan tujuan pendidikan nasional.

Dalam prakteknya, yakni kegiatan pembelajaran, teknologi juga dapat memberikan warna dan manfaat dalam pengembangan pendidikan agama Islam. Karena banyak varian yang digunakan baik berupa teori belajar, memilih kurikulum, memilih media dan sebagainya. Media sering dikaitkan dengan kata teknologi. Webster mengatakan bahwa teknologi tidak lebih dari suatu ilmu yang membahas tentang keterampilan yang diperoleh lewat pengalaman, studi, dan observasi. ${ }^{30}$ Selanjutnya, jika dikaitkan dengan pendidikan, Achsinn mengatakan bahwa teknologi merupakan perluasan konsep tentang media, dimana teknologi bukan sekadar benda, alat, bahan atau perkakas, tetapi tersimpul pula sikap, perbuatan, organisasi dan manajemen yang berhubungan dengan penerapan ilmu. ${ }^{31}$

Oleh karenanya, dalam kegiatan pembelajaran agama Islam di SD Negeri Candirejo, perlu menggunakan dan memaksimalkan media pembelajaran yang dapat menunjang terhadap pengembangan pendidikan agama Islam itu sendiri. Mulai dari pendidik yang harus memahami tentang agama, materi yang disampaikan, media yang

30 Merriam Webster, Webster's Ninth New Collegiate Dictionary, MerriamWebster Inc, 1983, hlm. 105.

31 A. Achsin, Media Pendidikan dalam Kegiatan Belajar-Mengajar, Ujung Pandang: IKIP Ujung Pandang, 1986, hlm.10.

PROGRESS - Volume 7, No. 1, Juni 2019 
digunakan maupun lingkungan yang ada harus dapat mengembangkan pendidikan agama Islam.

Disamping itu, kebijakan pemerintah maupun sekolah harus memperhatikan pendidikan agama Islam. Karena dengan kebijakan itulah seseorang bisa menerjemahkan ke dalam kegiatan belajar mengajar. Dalam hal ini, teknologi sangatlah memberi manfaat besar, yakni mempermudah siswa dalam menerima pelajaran. Disadari atau tidak, dengan adanya teknologi atau media dalam kegiatan pembelajaran siswa akan lebih tertarik jika dibandingkan dengan tidak menggunakan teknologi atau media. Akan tetapi jika pendidik tidak bisa memanfaatkannya dengan baik, semisal tidak bisa menggunakan atau gagap teknologi, maka itu akan memberi kesan tersendiri terhadap dirinya.

H. Pola-Pola Pembelajaran dan Peran Guru PAI di SD Negeri Candirejo

Sekurang-kurangnya ada lima pola pembelajaran, ${ }^{32}$ yaitu:

1. Pola Pembelajaran Tradisional.

2. Pola Pembelajaran Dibangu media.

3. Pola Pembelajaran Antara Guru dan Media.

4. Pola Pembelajaran dengan media.

5. Kombinasi pola sistem pembelajaran.

Pertama, pola pembelajaran tradisional. Dalam pola ini guru memegang peranan utama dalam menentukan isi dan metode pembelajaran, termasuk dalam menilai kemajuan belajar siswa. Jadi dalam pola pembelajaran tradisional, guru merupakan satu-satunya sumber belajar. Pola kedua, pembelajaran dibantu media. Pola 129.

${ }^{32}$ Nana Sudjana \& Rivai, Teknologi Pengajaran, Bandung: Sinar Baru, 2003, hlm. PROGRESS - Volume 7, No. 1, Juni 2019 
pembelajaran yang memanfaatkan media pengajaran sebagai sumber disamping guru. Pola ketiga, pembelajaran antara guru dan media.

Pola pembelajaran PAI ini, antara guru dan ahli media saling berinteraksi dengan siswa berdasarkan satu tanggung jawab bersama. Pola keempat, pembelajarna dengan media. Dalaam situasi belajar tertentu, yaitu apabila para siswa sudah mempunyai disiplin tinggi dalam belajar, latar belakang pengalaman belajar yang cukup, serta pola berfikir sudah matang, maka interaksi belajar mengajar bisa dilakukan langsung antara siswa dengan media pengajaran yang telah dieprsiapkan oleh para ahli emdia dan guru. Dengan demikian kehadiran guru kelas dapat digantikan oleh media yang diciptakannya. Media tersebut disebut guru media.

Sejalan dengan perkembangan teknologi informasi, maka guru tidak hanya terbatas perannya sebagia pengajar dalam arti penyampai pegnetahuan, akan tetapi plebih emmprosisikan diri sebagai "perancang epngajaran, pegnevaluasi hasil belajar dan sebagai direktur belajar". ${ }^{33}$

Sebagai perancang pengajaran (Designer of instruction), seorang guru PAI di SD Negeri Candirejo akan berperan mengelola seluruh proses pemeblajaran dengan menciptakan kondisi-kondisi belajar sedemikian rupa sehingga setuiap anak dapat belajar secara efektif dan efisien. Kegiatan belajar hendaknya dikelola dengan sebaik-baiknya sehingga memberikan suasana yang mendrong siswa untuk melakukan kegiatan belajar degan kualitas yang lebih baik.

Sebagai penilai hasil belajar siswa (evaluator of student learning), guru dituntut untuk berperan secara terus-menerus mengikuti hasil-hasil belajar yang dicapai oleh siswa dari waktu ke waktu.

${ }^{33}$ Gagne, R. M., The Conditions of Learning and Theory of Instruction. New York: CBS College Publishing, 1985, hlm. 230.

PROGRESS - Volume 7, No. 1, Juni 2019 
Informasi yang diperoleh melalui evaluasi ini akan merupakan umpan balik terahdap proses kegiatan belajar mengajar yang selanjutnya akan dijadikan titik tolak untuk memperbaiki dan meningkatkan proses belajar mengajar selanjutnya. Dengan demikian, proses belajar mengajar akan senantiasa ditingkatkan terus menerus untuk memperoleh hasil eblajar yang optimal.

Sebagai pengarah belajar (director of learning), guru berperan untuk senantiasa menimbulkan, memelihara, dan meningkatna motivasi siswa untuk belajar. Dalam hubungna ini, guru mempunyai peranan sebagai "Motivator keseluruhan kegiatan belajar siswa. Sebagai motivator belajar, guru SD Negeri Candirejo juga harus mampu untuk:

1. Membangkitkan dorongan siswa untuk belajar.

2. Menjelaskan secara konkrit kepada siswa apa yang dapat dilakukan pada akhir pengajaran.

3. Memberikan ganjaran untuk prestasi yang dicapai dikemudian hari.

4. Membuat regulasi (aturan perilaku siswa) sebagai direktur belajar.

Pendekatannya yang digunakan dalam proses pembelajaran tidak hanya melakukan pendekatan instruksional saja, akan tetapi disertai dengan pendekatna pribadi. Melalui pendekatan pribadi ini diharapkan guru dapat mengenal dan memahami siswa secara lebih mendalam, sehingga dapat membantu dalam keseluruhan proses belajarnya. Dengan kata lain, sebagia dierktur belajar, guru sekaligus berperan sebagai pembimbing dalam PBM.

Sebagai pembimbing dalam belajar, guru SD Negeri Candirejo juga diharapkan mampu untuk:

1. Mengenal dan memahami setiap siswa, baik secara idnividual maupun kelompok. 
2. Memberikan informasi-informasi yang diperlukan dalam proses belajar.

3. Memberikan kesempatan yang memadai agar setiap siswa dapat belajr sesuai dengan karakteristik pribadinya.

4. Membantu setiap siswa dalam menghadapi masalha-masalah pribadi yang diharapinya.

5. Menilai keberhasilan setiap langkah kegiatan yang telah dilakukan.

\section{Kesimpulan}

Berdasarkan penjelasan sebelumnya dapat diperoleh kesimpulan sebagai berikut:

1. Pemanfaatan Teknologi Informasi untuk Pembelajaran Pendidikan Agama Islam (PAI) di SD Negeri Candirejo dapat dikelompokkan ke dalam tiga fungsi, yaitu: a) Media Pembelajaran mandiri/klasikal; 2) Teknologi Informasi yang dimanfaatkan untuk alat bantu pembelajaran; 3) Teknologi Informasi yang terkait sebagai sumber belajar (learning resurces)

2. Pengembangan program belajar di SD Negeri Candirejo yaitu: a) Tahap program behavioral technology; b) Tahap instructional technology; c) Tahap performance technology.

3. SD Negeri Candirejo, perlu menggunakan dan memaksimalkan media pembelajaran yang dapat menunjang terhadap pengembangan pendidikan agama Islam itu sendiri. Guru PAI di SD Negeri Candirejo akan berperan mengelola seluruh proses pemeblajaran dengan menciptakan kondisi-kondisi belajar sedemikian rupa sehingga setuiap anak dapat belajar secara efektif dan efisien. Mulai dari memilih materi, teori, metode, teknik, strategi maupun media pembelajaran. 
4. Sebagai penilai hasil belajar siswa (evaluator of student learning), guru dituntut untuk berperan secara terus-menerus mengikuti hasilhasil belajar yang dicapai oleh siswa dari waktu ke waktu. Sebagai pengarah belajar (director of learning), guru berperan untuk senantiasa menimbulkan, memelihara, dan meningkatna motivasi siswa untuk belajar dan sebagai pembimbing dalam belajar 


\section{DAFTAR PUSTAKA}

Abdulhak. 2001. Rancang Bangun Konsep Teknologi Pendidikan, Bandung: Remaja Rosda Karya

Achsin, A. 1986. Media Pendidikan dalam Kegiatan Belajar-Mengajar. Ujung Pandang: IKIP Ujung Pandang

Bachari, A. Dutha. 2001. "Kejahatan (Intelektual) dalam dunia Cyber". Artikel pada Harian Umum Galamedia

Creswell, John W. 1994. Reseach design Qualitative \& Quantitative Approaches. United States of America: Sage Publication, 1994, hlm. 148.

Gagne, R. M. 1985. The Conditions of Learning and Theory of Instruction. New York: CBS College Publishing

Hadimiarsa, Yusuf. 1986. Teknologi Komunikasi Pendidikan. Jakarta: Rajawali

Ivor K. Davis. 1997. Teknologi Pendidikan "Contoh Yang Sempurna Paradigma dan Model'. London.

Janie, Umar A. 1998. Paradigma dan Regulitas Perkembangan IPTEK; dalamReliguisitas IPTEK, ed, Abdul Munir Mulkam, et.al. Yogyakarta: Pustaka Pelajar

Komaruddin. 1994. Ensiklopedi Manajemen. Jakarta: Bumi Aksara

Kuper, Adam dan Jessica Kuper. 2008. Ensiklopedi Ilmu-Ilmu Sosial. Jakarta: PT RajaGrafindo Persada

Majid, Abdul. 2004. Pendidikan Agama Islam Berbasisi Kompetensi. Bandung: PT Remaja Rosdakarya

Maslikhah. 2013. Melejitkan Kemahiran Menulis Karya Ilmiah Bagi Mahasiswa, Yogyakarta: Trusth Media Publishing 
Miarso, Yusuf Hadi. 2007. Menyamai Benih Tekhnologi Pendidikan. Jakarta: Rajawali Press

Miles, M.B \& Huberman. 1992. A.M, Analisa Data Kualitatif: Penerjemah. TjetjepRohendi R. Universitas Indonesia Press

Moleong, lexy J. 2011. Metodologi Penelitian Kualitatif. Bandung: Remaja Rosdakarya

Mudhoffir. 1996. Teknologi Instruksional. Bandung: Remaja Rosdakarya

Munir. 2008. Kurikulum Berbasis Tekhnologi Informasi dan Komunikasi. Bandung: Alfabeta

Nana Sudjana \& Rivai, 2003. Teknologi Pengajaran, Bandung: Sinar Baru

Nasution. 2008. Teknologi Pendidikan. Jakarta: Bumi Aksara

Norman K.Denzin. 2000. Handbook of Qualitative Research, California : Sage Publication, 2000, p. 391.

Percival, Fred dan Henry Ellington. 1998. Teknologi Pendidikan. Jakarta: Erlangga

Richey, R.C. 2008. Reflections on the 2008 AECT Definitions of the Field. TechTrends,

Rogers, Everett M. 1986. Communication Technology, The New Media in Society. New York. The Free Press.

Soejoeti. 1998. Al-Islam dan Iptek. Jakarta: Raja Grafindo

Wardhana, 2005. Wisnu Arya. Melacak Teori Einsten dalam Al-Qur'an. Yogyakarta: Pustaka Pelajar

Webster, Merriam. 1983. Webster's Ninth New Collegiate Dictionary. Merriam-Webster Inc

Yusuf Qardawi. 1998. Al-Qur'an bebicara tentang Akal dan Ilmu Pengetahuan. Jakarta: Gema Insani Press 